\title{
Robotic assisted thoracic surgery: advanced procedures in lung and mediastinum
}

In the era of minimally invasive surgery, thoracic surgeons have video-assisted thoracoscopic surgery (VATS) and robotassisted thoracoscopic surgery (RATS) in their arsenal. However, when the procedure becomes challenging most surgeons prefer open thoracotomy to ensure safety and good oncological outcomes.

Robotic surgery has grown in last decades with nowadays few expert surgeons pushing the limits of this approach to perform some complex cases with excellent results.

This series cover the new fields of advanced procedures in lung and mediastinum with different authors reporting their experiences in order to help thoracic surgeons already comfortable with the robot platform and who are looking for tips and tricks to progress in more difficult cases.

We will develop the surgery following induction treatment, with a particular attention on pulmonary resection after immunotherapy which will be more and more common in the near future because of the large adoption of this treatment for patients with lung cancer.

We will detail anatomical infra lobar resections that will be practiced more often for small peripherized non-small cell lung cancer, and a focus on challenging atypical segmentectomies and the situation with multiple segments to resect.

We will show the great help of the robot for the borders of the thoracic cavity, especially for the apex thanks to the camera and the multiport access.

We will report the advantage of the robot when reconstruction is needed, and the ease of suturing for bronchial sleeve lobectomies.

We will explain the management of pulmonary artery bleeding during a robotic procedure in order to secure the procedure as much as possible.

We will review thymic resections and demonstrate the contribution of $\mathrm{CO}_{2}$ inflation for mediastinal procedures.

In conclusion, this series will emphasize the benefit of the robotic platform for the patients and the surgeon. Indeed, it ensures surgical dexterity, mandatory for these complex cases requiring hard skill and bimanual dissection. Thus, the robot offers an open surgery in a closed chest with advanced tools (as fluorescence or image-assisted surgery or dual console), allowing to push the border of the minimally invasive approach.

\section{Acknowledgments}

Funding: None.

\section{Footnote}

Provenance and Peer Review: This article was commissioned by the editorial office, Fournal of Visualized Surgery for the series "Robotic Assisted Thoracic Surgery: Adavanced Procedures in Lung and Mediastinum: From Post-induction TTT (immunotherapy) to Sleeve Resection, Complex Segmentectomies and Extended Thymectomy for Myasthenia Gravis". The article did not undergo external peer review.

Conflicts of Interest: Both authors have completed the ICMJE uniform disclosure form (available at https://jovs.amegroups. com/article/view/10.21037/jovs-21-44/coif). The series "Robotic Assisted Thoracic Surgery: Adavanced Procedures in Lung and Mediastinum: From Post-induction TTT (immunotherapy) to Sleeve Resection, Complex Segmentectomies and Extended Thymectomy for Myasthenia Gravis" was commissioned by the editorial office without any funding or sponsorship. JMB served as the unpaid Guest Editor of the series. JMB reports personal fees from Intuitive Surgery, Medtronic, and Johnson and Johnson, outside the submitted work. The authors have no other conflicts of interest to declare. 
Ethical Statement: The authors are accountable for all aspects of the work in ensuring that questions related to the accuracy or integrity of any part of the work are appropriately investigated and resolved.

Open Access Statement: This is an Open Access article distributed in accordance with the Creative Commons AttributionNonCommercial-NoDerivs 4.0 International License (CC BY-NC-ND 4.0), which permits the non-commercial replication and distribution of the article with the strict proviso that no changes or edits are made and the original work is properly cited (including links to both the formal publication through the relevant DOI and the license). See: https://creativecommons.org/licenses/by-ncnd $/ 4.0 /$.

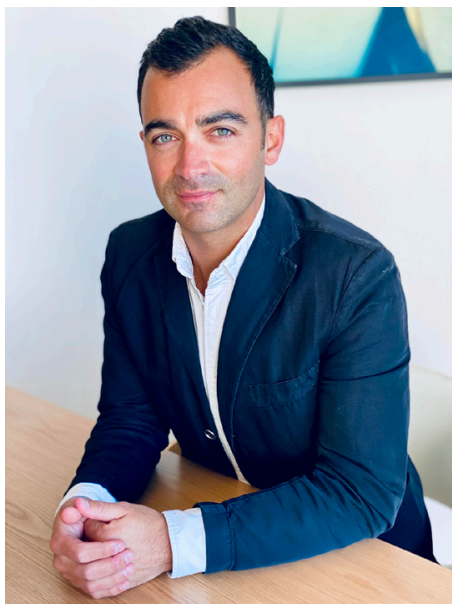

Ilies Bouabdallah

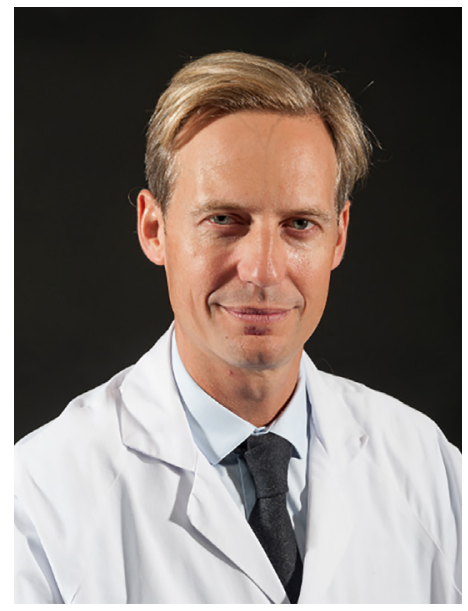

Jean-Marc Baste

Ilies Bouabdallah

Department of Thoracic Surgery, Hospital Saint Joseph, Marseille, France.

(Email: ibouabdallab@hopital-saint-joseph.fr)

Jean-Marc Baste

Department of General Thoracic Surgery, Rouen University Hospital, Rouen, France.

(Email: Jean-Marc.Baste@chu-rouen.fr)

Received: 13 July 2021; Accepted: 02 August 2021; Published: 20 October 2021.

doi: $10.21037 /$ jovs-21-44

View this article at: https://dx.doi.org/10.21037/jovs-21-44

doi: 10.21037/jovs-21-44

Cite this article as: Bouabdallah I, Baste JM. Robotic assisted thoracic surgery: advanced procedures in lung and mediastinum. J Vis Surg 2021;7:36. 